\title{
Rewitalizacja jako element polityki równoważenia rozwoju funkcjonalno-przestrzennego
}

\author{
Hanna Borucińska-Bieńkowska, Alicja Maciejko
}

\author{
Katedra Architektury i Urbanistyki, Uniwersytet Zielonogórski, \\ e-mail: h.borucinska-bienkowska@aiu.uz.zgora.pl
}

Streszczenie: Transformacja społeczno-gospodarcza w Polsce, w ciągu ostatnich dekad, spowodowała wiele różnorodnych zjawisk, w tym także na płaszczyźnie rozwoju funkcjonalno-przestrzennego. Procesy rewaloryzacji, modernizacji, renowacji budynków mieszkalnych i obiektów budowlanych, a także rewitalizacji obszarów funkcjonalnych pełnią istotną rolę $\mathrm{w}$ kształtowaniu polityki zrównoważonego rozwoju miast oraz gmin. Przywracanie dawnych wartości estetycznych, kulturowych, a także materialnych obiektów oraz całych zespołów budynków, układów urbanistycznych i ruralistycznych wystąpiło w kraju, ze szczególną atencją, na początku lat dziewięćdziesiątych XX wieku. Procesy te odgrywają znaczącą rolę, nie tylko w przywracaniu świetności dawnych obiektów i założeń urbanistycznych, ale także w kształtowaniu świadomości lokalnych społeczności, dotyczącej wartości środowiska materialnego minionych lat, w tym również z lat 60 i $70 \mathrm{XX}$ wieku. Artykuł porusza zagadnienia związane z procesem rewitalizacji mającymi wpływ na kształtowania równoważenie rozwoju terenów zurbanizowanych. Podkreślić należy, że dla ww. działań istotne jest wskazanie kierunków komunikacji społecznej oraz zakresu współodpowiedzialności za program rewitalizacji samorządów i lokalnych społeczności.

Słowa kluczowe: rewitalizacja obszarów funkcjonalnych, rewaloryzacja, modernizacja, renowacja.

\section{Wstęp}

Transformacja społeczno-gospodarcza w Polsce na przestrzeni ostatnich trzech dekad spowodowała zarówno wiele korzystnych zmian, jak i występowanie negatywnych procesów funkcjonalno-przestrzennych związanych z chaotyczną rozbudową na terenach gmin wiejskich będących w strefie wpływu dużego miasta. Restrukturyzacja, prywatyzacja lub bankructwo firm, zakładów przemysłowych, zmiany w PKP i Wojsku Polskim doprowadziły do wystąpienia w polskiej przestrzeni licznych terenów wymagających przekształceń oraz nowego zagospodarowania funkcjonalno-przestrzennego. Niszczejące zabytki, zdekapitalizowane tereny cenne historycznie, opuszczone i popadające w ruinę tereny poprzemysłowe oraz pokolejowe, zdegradowane tereny powojskowe i po dawnych PGR-ach wymagają rewitalizacji. Znajdujące się na nich obiekty budowlane potrzebują modernizacji, adaptacji lub gruntownego remontu. Problematyka rewitalizacji odgrywa istotną rolę w kształtowaniu wielu przestrzeni zurbanizowanych. Wywiera także wpływ na świadomość władz samorządowych i lokalnych społeczności dotyczącą między innymi wartości środowiska przyrodniczego i materialnego minionych lat. Lokalne władze samorządowe stanęły przed wyzwaniem realizacji zadań wynikających między innymi z Narodowej Strategii Rozwoju Regionalnego, która określiła rewitalizację jako 
przedmiot planowania przestrzennego. Akcesja Polski do Unii Europejskiej (1 maja 2004 r.) umożliwiła pozyskanie środków finansowych przeznaczonych na ten cel z funduszy europejskich. Było to możliwe poprzez Zintegrowany Program Operacyjnego Rozwoju Regionalnego, jeden z siedmiu programów realizujących Narodowy Plan Rozwoju. Narodowe Strategiczne Ramy Odniesień (NSRO) z 2007 r. przedstawiały między innymi strategię rozwoju społecznego i gospodarczego kraju, cele polityki spójności oraz określały system wdrażania funduszy unijnych. Dokument ten zawierał między innymi 16 Regionalnych Programów Operacyjnych odnoszących się do poszczególnych województw i określających zasady tworzenia oraz realizacji programów rewitalizacji. Podkreślić należy, że procesy rewitalizacji dotyczące obszarów kryzysowych, w zakresie przestrzeni, funkcji oraz środowiska społecznego, obejmują przede wszystkim tereny zurbanizowane. Znacznie rzadziej spotykamy takie działania w obszarach wiejskich, parkach dworskich, w środowisku przyrodniczym. Rewitalizacja jednak odnosi się zarówno do zagadnień urbanistycznych, ruralistycznych, przyrodniczych, krajobrazowych oraz architektonicznych, jak i społecznych oraz gospodarczych.

Definicja rewitalizacji podana przez prof. Krzysztofa Skalskiego w 2002 roku brzmi: „Rewitalizacja określana jest jako kompleksowy program remontów, modernizacji zabudowy i przestrzeni publicznych, rewaloryzacji zabytków na wybranym obszarze, najczęściej dawnej dzielnicy miasta, w powiązaniu z rozwojem gospodarczym i społecznym. Rewitalizacja to połączenie działań technicznych - jak np. remonty - z programami ożywienia gospodarczego i działaniem na rzecz rozwiązania problemów społecznych, występujących na tych obszarach: bezrobocie, przestępczość, brak równowagi demograficznej."1

Natomiast w 2004 r. K. Skalski pisze, że rewitalizacja obejmuje wszystkie zakresy takie jak remonty, modernizacje, rewaloryzacje, a pojęcie to odnosi do: ,....kompleksowych akcji podejmowanych w obszarach miasta, szczególnie starych dzielnicach zdegradowanych..."2

W 2005 r. C.A. Heller definiuje: rewitalizacja ,...oznacza proces zmian przestrzennych, technicznych, społecznych i gospodarczych podjętych w interesie publicznym, których celem jest wyprowadzenie obszaru z sytuacji kryzysowej, przywrócenie mu dawnych funkcji oraz stworzenie warunków do jego dalszego rozwoju z wykorzystaniem cech endemicznych"3

Definicja rewitalizacji, zapisana w projekcie wytycznych Ministerstwa Gospodarki i Pracy, brzmi następująco: „Kompleksowe, zintegrowane, lokalne, kilkuletnie programy zainicjowane przez władze lokalne (w szczególności gminne), mające na celu realizację działań technicznych, społecznych i gospodarczych - w zgodzie z zasadami spójności terytorialnej oraz ochrony środowiska - w rozmaitych obszarach miejskich, zdegradowanych obszarach miejskich, obszarach poprzemysłowych i powojskowych."

Takie wszechstronne rozumienie rewitalizacji pozwala na wielopłaszczyznowe przedsięwzięcia zarówno w środowisku funkcjonalno-przestrzennym oraz społecznym i gospodarczym. Ograniczanie działań tylko do remontów, modernizacji, czy odbudowy obiektów budowlanych nie przyniesie pożądanych efektów w sferze społecznej oraz gospodarczej. Proces rewitalizacji ma charakter działań kompleksowych, nie może ograniczać się do jednego, wybranego elementu.

\footnotetext{
1 K. Skalski, Rewitalizacja obszarów starej zabudowy w miastach, s. 1, KIN, Kraków 2002.

2 K. Skalski, Szanse i zagrożenia rewitalizacji w Wykluczenie, rewitalizacja, spójność społeczna, s. 85, Ślasksp. z o. o. Wydawnictwo Naukowe, Katowice-Warszawa 2004.

${ }^{3}$ C. A. Heller, Rewitalizacja obszarów miejskich. Praktyczny przewodnik: Jak opracować lokalny plan rozwoju, EFRR w Polsce, 2005.

${ }^{4}$ Za ibidem s. 7.
} 


\section{Wybrane elementy wprowadzania programu rewitalizacji}

Pierwszym elementem w procesie rewitalizacji jest konieczność wyszczególnienia przyczyn rozpoczęcia ww. przedsięwzięcia, opis sekwencji działań i metody pracy, powołanie osób lub instytucji odpowiedzialnych, przedstawienie zastosowanych przepisów i aktów prawnych, a także określenie sposobu finansowania. Charakterystyka i diagnoza stanu istniejącego może opierać się na porównywaniu danych statystycznych oraz wszelkich dostępnych informacji dotyczących sfer funkcjonalno-przestrzennych, gospodarczych i społecznych. Analizie należy także poddać stan środowiska przyrodniczego, w wymaganym dla danego przedsięwzięcia zakresie.

Sfera funkcjonalno-przestrzenna wymaga określenia struktury komunikacji kołowej i pieszej, infrastruktury technicznej, obiektów i stref ochrony konserwatorskiej, przestrzeni publicznych i terenów sportowo-rekreacyjnych, a także stanu środowiska przyrodniczego.

W strefie gospodarczej należy określić między innymi strukturę i rodzaj podmiotów gospodarczych działających na rewitalizowanym terenie, głównych pracodawców i strukturę zatrudnienia oraz kierunki rozwoju gospodarczego rejonu, w którym znajduje się obszar opracowania.

W strefie społecznej badaniami należy objąć:

- stan demograficzny, strukturę wieku, poziom wykształcenia i zatrudnienia,

- stan bezrobocia i poziom ubóstwa,

- możliwość dostępu do edukacji i infrastruktury społecznej,

- aktywność lokalnej społeczności i organizacji pozarządowych,

- funkcjonowanie lokalnych samorządów.

Analizy i uwarunkowania w badanych sferach należy zdiagnozować oraz określić słabe i mocne strony oraz szanse i zagrożenia (SWOT). Ww. działania powinno się prowadzić w oparciu o dokumenty strategiczne, a także planistyczne dla miasta i gminy, rejonu, powiatu, województw oraz kraju (w zależności od potrzeb). Istotnym dla realizacji założeń programu rewitalizacji jest także okres ich wdrażania, czas realizacji i zasięg terytorialny. Ważnym elementem są również lokalne tradycje, historyczne uwarunkowania oraz oczekiwania społeczne. Odnosząc się do przewidywanych nakładów materialnych oraz efektów prac w sferze funkcjonalno-przestrzennej i społeczno-gospodarczej będących skutkami rewitalizacji należy szczegółowo przeanalizować i zbilansować źródła finansowania. Wdrażanie programu rewitalizacji dla danego obszaru funkcjonalnego, poprzez określenie operatora i sposobu jego działania, winno być monitorowane zarówno na etapie programu rewitalizacji, jego oceny, sposobu wprowadzania poszczególnych elementów, jak i współpracy z lokalną społecznością, samorządem, gospodarczym sektorem prywatnym i publicznym, organizacjami pozarządowymi i innymi podmiotami mającymi wpływ na Public Relations rewitalizacji.

Niezwykle istotnym uwarunkowaniem formalno-prawnym jest zagadnienie związane między innymi z prawem własności. Brak uregulowań w tej dziedzinie prowadzi niejednokrotnie do opóźnienia lub zaniechania podjętych działań renowacji, modernizacji, czy adaptacji obiektu do nowych warunków.

Rozpoczęcie rewitalizacji obszarów funkcjonalno-przestrzennych następuje w oparciu o dokumenty strategiczne oraz planistyczne na poziomie gminy, miast, powiatu i województwa, w wymaganym dla celu prac zakresie. Dotyczy to strategii rozwoju województw, regionalnego programu operacyjnego, strategii rozwoju gminy, miasta i powiatu, studium uwarunkowań i kierunków zagospodarowania przestrzennego miasta oraz gminy oraz miejscowych planów zagospodarowania przestrzennego. Odnosi się także do dokumentów dotyczących 
polityki w różnych dziedzinach społecznych i gospodarczych, np.: ochrony środowiska geograficznego i przyrodniczego w tym wyszczególnienie cennych obszarów przyrodniczych, gruntów rolnych i leśnych, dziedzictwa historycznego i zasobów kultury materialnej, infrastruktury technicznej, transportowej i komunikacji. Bardzo ważnymi są zagadnienia społeczne oraz gospodarcze, ze szczególnym uwzględnieniem programów przeciwdziałania patologiom społecznym.

Dla prawidłowego przeprowadzenia wszystkich działań istotnych z punktu widzenia celu jakim jest rewitalizacja obszaru, znaczenie ma określenie nie tylko jej zasięgu terytorialnego, ale także określenie ram czasowych. Umożliwi to realizację przyjętych programów oraz właściwe postępowanie na wielu płaszczyznach, w tym także racjonalne gospodarowanie środkami finansowymi. Zdefiniowanie sposobu oraz form prawnych realizacji programu rewitalizacji, w tym zakresu możliwości realizacyjnych, uprawnień, obowiązków oraz odpowiedzialności dla poszczególnych operatorów, pozwoli na prawidłowe jego wykonanie. Istotne dla ww. działań jest również określenie procedur komunikacji społecznej, porozumienia między jednostkami oraz zainteresowanymi grupami osób w zakresie współtworzenia i współodpowiedzialności. Szczególnie rewitalizacja obszaru dysfunkcyjnego, w którym występują problemy nie tylko funkcjonalno-przestrzenne, ale przede wszystkim społeczne i ekonomiczne, wymaga prawidłowej współpracy między wszystkimi jednostkami oraz organizacjami. Dlatego dobry program promocji i uświadamiania konieczności rewitalizacji jest jednym ze sposobów komunikacji społecznej.

\section{Zachowanie dziedzictwa historycznego jako element rewitalizacji}

Wdrażane programy rewitalizacji stanowią element działań dążących do nadania zdegradowanym obiektom i terenom nowych form oraz funkcji. Zachowanie dziedzictwa narodowego i lokalnych tradycji powinno być jednym z priorytetów przy ich wprowadzeniu. W projektach rewitalizacji można wyróżnić kilka jej typów:

1. rewitalizacja zdegradowanych centrów miast i wielofunkcyjnych przedwojennych obszarów zabudowy miejskiej,

2. rewitalizacja miast o wysokich walorach turystycznych,

3. rewitalizacja obszarów zagrożonych problemami społecznymi i gospodarczymi,

4. rewitalizacja wielorodzinnych osiedli mieszkaniowych, w tym zwłaszcza wzniesionych w technologii wielkiej płyty,

5. rewitalizacja obszarów zamieszkanych przez ludność zagrożoną wykluczeniem społecznym,

6. rewitalizacja terenów poprzemysłowych, pokolejowych oraz powojskowych,

7. rewitalizacja terenów stykowych znajdujących się pomiędzy strukturami miejskimi a rzekami (Waterfront),

8. rewitalizacja krajobrazu miasta i terenów wiejskich, ze szczególnym uwzględnieniem ich sylwety i panoramy.

Zmiany funkcjonalno-przestrzenne z minionych lat, które doprowadziły do zniszczeń w polskim krajobrazie miejskim i wiejskim, są trudne do odwrócenia. Chaotyczna zabudowa centrów miast budynkami wielokondygnacyjnymi, często zasłaniającymi historyczne osie widokowe i panoramy, nie poprawia tej sytuacji. Rozwój funkcjonalno-przestrzenny miast jest nieunikniony, jednak należy działać z olbrzymią rozwagą oraz pokorą w stosunku do dziedzictwa kulturowego i historycznej zabudowy. Historyczne układy urbanistyczne miast nie mogą zapewnić prawidłowej obsługi dla lawinowo rosnącej liczby użytkowników spo- 
wodowanej np. wybudowaniem na niewielkiej działce śródmiejskiej kilkudziesięcio-kondygnacyjnego biurowca generującego dodatkowy ruch kołowy. Inwestycje takie wywołują konieczność działań mających na celu przekształcenia funkcjonalno-przestrzenne, które poprawią życie mieszkańców oraz zachowają cenne wartości środowiska historycznego i kultury materialnej.

Rewitalizacja ma także na celu przekształcenie istniejącego niepożądanego stanu, poprzez wprowadzanie zasad zrównoważonego rozwoju. Na ten proces składają się działania na płaszczyźnie ekologicznej, ekonomicznej i społecznej. Ekonomiczne oraz gospodarcze aktywizują lokalną społeczność do przemian oraz rozwoju. Z kolei funkcjonalno-przestrzenne, związane z przywróceniem wartości, poprzez modernizację obiektów wpływają na poprawę jakości życia mieszkańców. Remonty uzupełnione wprowadzeniem nowych dodatkowych rozwiązań, związanych również z ekologią i energią odnawialną podnoszą komfort życia. Przywrócenie obiektom, kwartałom, dzielnicom o szczególnych wartościach historycznych i kulturowych stanu świetności, przy zachowaniu lub zmianie funkcji jest również celem rewitalizacji.

Stałym oraz systematycznym działaniem mającym na celu utrzymanie obiektu, kwartału, dzielnicy w wymaganym stanie technicznym jest przeprowadzanie szczegółowej inwentaryzacji, w tym także fotograficznej, a także ciągłe monitorowanie tego stanu w celu określenia zakresu oraz terminu koniecznych prac.

Programy i dokumenty związane z rewitalizacją mają sprzyjać realizowaniu interesów różnych grup społecznych, kierować i stabilizować działania samorządów, zapobiegać napięciom i rozczarowaniu lokalnych społeczności. Rewaloryzacja powinna zakładać wieloletni program działań, który wyprowadza obszar objęty tymi postępowaniami ze stanu kryzysowego oraz zapewnia jego zrównoważony i trwały rozwój. Kontynuuje również działania, w celu dalszego postępu, poprzez powiązanie zagadnień rozwoju gospodarczego ze wzrostem świadomości społecznej przy zachowaniu lokalnej tożsamości mieszkańców. Programy powinny zakładać ponadto zintegrowane podejście do omawianych zagadnień, poprzez ich wzajemne powiązanie, w ramach wspólnych przedsięwzięć w zakresie struktury i działalności społecznej, gospodarczej, usług publicznych, środowiska naturalnego, komunikacji, infrastruktury technicznej oraz ponadlokalnych celów publicznych. Tylko szeroko pojęta integracja władz samorządowych i lokalnych społeczności oraz współpraca na wszystkich płaszczyznach może przynieść szybkie i pożądane efekty.

\section{Przedsięwzięcia techniczne jako element rewitalizacji}

Przywrócenie stanu technicznego i wprowadzenie nowego zastosowania obiektów, tak aby wykorzystać ich potencjał funkcjonalno-przestrzenny, jest jednym z celów rewitalizacji. Jednak przekazanie budynków do użytkowania nie oznacza zaprzestania wszystkich prac budowlanych. Dobry stan techniczny obiektów budowlanych oraz ich infrastruktury zależy przede wszystkim od eksploatacji i odpowiedniej, ciągłej konserwacji. Użytkowanie obiektu jest także elementem eksploatacji środowiska zarówno zurbanizowanego, jak i naturalnego.

Jan Maciej Chmielewski w Teorii Urbanistyki pisze: ,...w każdym obiekcie zbudowanym mają miejsce prace budowlane o różnym nasileniu oraz zaangażowaniu środków finansowych i materialnych, tak długo, jak długo taki obiekt jest użytkowany. Sekwencja tych prac układa się według następującego schematu:

faza 1 - wznoszenie budynku,

faza 2 - bieżące konserwacje, naprawy i remonty, 
faza 3 - remont kapitalny,

faza 4 - bieżące konserwacje, naprawy i remonty,

faza 5 - remont kapitalny wraz z modernizacją,

faza 6 - bieżące konserwacje, naprawy i remonty,

faza 7 - remont kapitalny itd.".

[Chmielewski J. M., Teoria Urbanistyki Warszawa, 2010 r., str. 147].

Ww. fazy przez wiele lat w Polsce ograniczone były do 1 i 2, a 3 omijano z powodu braku środków finansowych. Remonty kapitalne i modernizacje należą do trudnych przedsięwzięć. Należy je bowiem prowadzić między innymi również w ścisłym powiązaniu i z zaangażowaniem użytkowników przekształcanych obiektów. Nie zawsze przygotowani do zmian, często wnoszą oni partykularne roszczenia, nieuwzględniające dobra ogółu, czy współczesnych rozwiązań zarówno funkcjonalnych, jak i technicznych.

Przeprowadzane w ostatnich latach termomodernizacje budynków ograniczały się tylko do wymiany okien na plastikowe i izolowanie ścian zewnętrznych styropianem. Brak wykonania innych elementów remontu, w tym usprawnienia lub wykonania właściwej wentylacji pomieszczeń, wymiany lub gruntownej naprawy wszystkich instalacji, wprowadzenia usprawnień dla osób niepełnosprawnych, powodowało wiele negatywnych skutków funkcjonalnych i eksploatacyjnych w obiektach. Liczne awarie instalacji gazowych, które niejednokrotnie powodowały ofiary śmiertelne drastycznie wskazują na konieczność właściwego prowadzenia modernizacji obiektów budowlanych. Ww. działania wymagają kompleksowych i profesjonalnych rozwiązań technicznych. Rewitalizacja funkcjonalno-przestrzenna musi odbywać się w sposób komplementarny, nie może ograniczać się tylko do niektórych elementów przestrzeni lub infrastruktury budynku. Powinna obejmować całe spektrum działań na wszystkich płaszczyznach procesu oraz doprowadzić do stanu umożliwiającego wykorzystanie potencjału społecznego i gospodarczego rekapitalizowanych obiektów i terenów. Proces rewitalizacji jest złożony i wielowarstwowy, a ww. definicje rewitalizacji ulegają przekształceniom i modyfikacjom. Uzupełnianie działań w zależności od występujących przeszkód, zarówno funkcjonalno-przestrzennych, jak i społeczno-gospodarczych, jest wyzwaniem dla osób i instytucji podejmujących rozwiązywanie problemów technicznych. Jest koniecznym postępowaniem prowadzącym do poprawy życia mieszkańców przekształcanych obszarów funkcjonalnych.

\section{Rozwiązania ekologiczne jako element rewitalizacji}

W analizowaniu procesów i zagadnień rewitalizacji funkcjonalno-przestrzennej terenów zurbanizowanych nie można pominąć aspektu ekologicznego i konieczności ochrony obszarów przyrodniczych, zarówno objętych ochroną prawną korytarzy ekologicznych, systemów zieleni, stref ważnych dla ochrony różnorodności florystycznej i faunistycznej oraz siedliskowej jako potencjalnych form ochrony przyrody. Dla osiągnięcia koherencji systemów przyrodniczych, konieczne jest włączenie ich w procesy rewitalizacji terenów zurbanizowanych. Jednym z elementów mających na celu zachowanie kształtowania właściwej struktury ekologicznej obszarów funkcjonalnych jest ochrona i odtwarzanie korytarzy ekologicznych. Pełnią one decydującą rolę w systemie stabilnego i trwałego funkcjonowania fauny i flory obszarów zurbanizowanych. Mogą prawidłowo funkcjonować tylko pod warunkiem ich ciągłości w skali lokalnej, regionalnej, krajowej oraz kontynentu. Uwzględnienie ich w procesach rewitalizacji jest jednym z warunków zrównoważonego rozwoju obszarów funkcjonalnych. 


\title{
6. Konkluzja
}

Rewitalizacja jest wszechstronnym procesem skierowanym przede wszystkim na obszary zurbanizowane. Odnosi się do wielu dziedzin życia i nie może obejmować tylko działań technicznych. Prowadzona na terenach kryzysowych obejmuje zarówno funkcję, przestrzeń, substancję jak i sferę społeczno-gospodarczą. Rewitalizacja nie może ograniczać się do wybranego elementu, musi mieć charakter komplementarny. Przywrócenie możliwości wykorzystania całego potencjału terenu, znalezienie nowych i zastosowanie właściwych funkcji jest celem rewitalizacji. Zatem wybór obszarów przeznaczonych do rewitalizacji odnosi się zarówno do przestrzeni urbanistyczno-architektonicznej, jak i społeczno-gospodarczej.

\section{Literatura}

[1] Borucińska-Bieńkowska H. Rewitalizacja jako proces przemian przestrzennych, społecznych i ekonomicznych. w Wspótczesne problemy budownictwa. Teoria i praktyka. Politechnika Częstochowska, s. 11-19, Częstochowa 2015.

[2] Chmielewski J.M. Teoria urbanistyki w projektowaniu i planowaniu miast. Oficyna Wydawnicza Politechniki Warszawskiej, Warszawa 2010.

[3] Czarnecki W. Problemy rewitalizacji w gospodarce przestrzennej XXI wieku. Wyższa Szkoła Finansów i Zarządzania, Białystok 2006.

[4] Heller C. A. Rewitalizacja obszarów miejskich. Praktyczny przewodnik: Jak opracować lokalny plan rozwoju? Europejski Fundusz Rozwoju Regionalnego w Polsce, 2005.

[5] Koncepcja Przestrzennego Zagospodarowania Kraju 2030, Ministerstwo Rozwoju Regionalnego, Warszawa 2011.

\section{Revitalization as part of policy on sustainable functional-spatial development}

\author{
Hanna Borucińska-Bieńkowska, Alicja Maciejko
}

\author{
Department of Architecture and Urban Planning, Uniwersity of Zielona Góra, \\ e-mail: h.borucinska-bienkowska@aiu.uz.zgora.pl
}

\begin{abstract}
Socio-economic transformation of the past few decades in Poland has initiated a multitude of diverse phenomena, also in functional-spatial development. Processes of redevelopment, modernization, renovation of houses and other structures, and of revitalization of functional areas play a vital role in shaping policies of sustainable development of cities and communes. Restoration of aesthetic and cultural values and historic property, i.e. individual buildings as well as whole complexes and urban and rural planning systems after years of neglect, was given special attention at the beginning of the 1990s. The processes play an important role in bringing back old buildings, structures and urban planning conceptions to their former glory, and are also vital in shaping awareness of self-governmental authorities and local communities in terms of values of tangible heritage, including the 1960s and 1970s. The article discusses issues of the revitalization process as a tool to shape policy of sustainable
\end{abstract}


development of urbanized areas. It should be highlighted that the above-mentioned actions require clear directives about social communication and the extent of shared responsibility for the programme to revitalize self-governments and local communities.

Keywords: revitalization of functional areas, urban redevelopment, modernization, renovation. 